\title{
Analisis Kemampuan Pendapatan Asli Daerah Untuk membiayai Belanja Daerah Pada Pemerintah Kabupaten Jombang
}

\author{
Rika Viara ${ }^{1 *}$, Lilik Pujiati² \\ Sekolah Tinggi Ilmu Ekonomi PGRI Dewantara \\ *Korespondensi : Rikaviara9@Gmail.com
}

\begin{abstract}
Abstrak
Permasalahan yang dihadapi oleh Pemerintah Daerah Kabupaten Jombang diantaranya yaitu masih lemahnya kemampuan Pendapatan Asli Daerah, sehingga akan berpengaruh langsung terhadap Pendapatan Daerah yang merupakan sumber keuangan untuk membiayai Belanja Daerah. Tujuan penelitian ini untuk menganalisis dan memberikan penjelasan mengenai kemampuan Pendapatan Asli Daerah dalam memenuhi Belanja Daerah pada Pemerintah Daerah Kabupaten Jombang. Metode analisis yang digunakan yaitu metode kualitatif dengan menggunakan teknik triangulasi dan perhitungan beberapa rasio. Hasil penelitian ini menjelaskan bahwa kemapuan Pendapatan Asli Daerah Kabupaten Jombang dilihat dari segi analisis varians sudah dapat memenuhi kebutuhan dana dalam penyelenggaraan tugas - tugas Pemerintahan. Dari segi evektifitas Pendapatan Asli Daerah Pemerintah Daerah Kabupaten Jombang dinyatakan sangat evektif serta Belanja Daerah pada Pemerintah Daerah Kabupaten Jombang sangat efisien. Dilihat dari rasio keuangan dalam hal ini, derajat desentralisasi masih sangat rendah. Pemerintah Daerah Kabupaten Jombang belum mampu mengelola dan mengoptimalkan Pendapatan Asli Daerahnya, sehingga masih sangat tergantung terhadap pendapatan transfer/ dana perimbangan dari Pemerintah Pusat. Sebaiknya Pemerintah Daerah Kabupaten Jombang berusaha untuk meningkatkan Pendapatan Asli Daerahnya dengan cara menggali, mengembangkan dan mengelola potensi maupun sumber daya yang tersedia agar Kabupaten Jombang menjadi Kabupaten mandiri tanpa ketergantungan yang besar terhadap bantuan dana dari Pemerintah Pusat maupun Provinsi.

Kata Kunci : APBD, Belanja Daerah, Pemerintah Daerah Kabupaten Jombang, Pendapatan Asli Daerah.
\end{abstract}

\begin{abstract}
The problems faced by the Regional Government of Jombang Regency include the still weak ability of Local Revenue, so that it will have a direct effect on Regional Income which is a financial source to finance Regional Expenditures. The purpose of this study was to analyze and provide an explanation of the ability of Local Revenue in meeting Regional Expenditures in the Regional Government of Jombang Regency. The analytical method used is a qualitative method using triangulation techniques and calculation of several ratios. The results of this study explain that the ability of Jombang Regency Original Revenue in terms of analysis of variance has been able to meet the needs of funds in the implementation of Government tasks. In terms of effectiveness of Regional Revenue, the Regional Government of Jombang Regency was declared very effective and Regional Expenditures in the Regional Government of Jombang Regency were very efficient. Judging from the financial ratio in this case, the degree of decentralization is still very low. The Regional Government of Jombang Regency has not been able to manage and optimize its Regional Original Income, so it is still very dependent on the transfer income / balance funds from the Central Government. It is better for the Jombang Regency Government to try to increase its Regional Original Income by exploring, developing and managing the potential and available resources so that Jombang Regency becomes an independent Regency without a large dependence on funding assistance from the Central and Provincial Governments.

Keywords: Regional Budget, Regional Expenditures, Jombang District Government, Local Revenue.
\end{abstract}

\section{A. Pendahuluan}

Indonesia adalah negara kesatuan berbentuk Republik, dengan jumlah penduduk 260 juta orang yang tersebar pada 17.558 pulau, hidup dalam sembilan belas lingkungan hukum adat, dan terdiri dari kurang lebih 300 etnik. Selain itu luas wilayah Indonesia terdiri dari luas wilayah daratan $1.99 .170 \mathrm{~km}$ persegi dan luas wilayah perairan atau lautan $\pm 5,4$ juta $\mathrm{km}$ persegi, sehingga keseluruhannya mencapai $\pm 7,3$ juta $\mathrm{km}$ persegi. Jadi bisa dikatakan 
perbandingan luas wilayah daratan dan luas wilayah lautan sekitar $1: 3$ dan sangat jelas memerlukan suatu administrasi negara yang mampu menghubungkan pulau- pulau tersebut satu dengan yang lainnya sehingga pulau satu dengan pulau lainnya tidak terisolasi. Untuk dapat melancarkan jalannya sistem administrasi negara secara berdayaguna dan berhasilguna, maka tepatlah kiranya para pendiri negara ini memutuskan kalau wilayah Indonesia dibagibagi dalam wilayah yang lebih kecil. Hal tersebut terbukti dalam pasal 18 Undang- Undang Dasar 1945 yang menyatakan bahwa "Pembagian daerah Indonesia atas daerah besar dan kecil, dengan bentuk susunan pemerintahanannya ditetapkan dengan Undang- Undang, dengan memandang dan mengingat dasar permusyawaratan dalam sistem pemerintah negara, dan hakhak asal usul dalam daerah- daerah yang bersifat istimewa". Agar dapat mewujudkan keinginan tersebut, maka telah dikeluarkan Undang- Undang mengenai Pemerintah Daerah sebagaimana dimaksud dalam pasal 18 Undang- Undang Dasar 1945. Sampai dengan saat ini UndangUndang yang masih berlaku adalah Undang- Undang nomor 23 Tahun 2014 Tentang Pemerintahan Daerah merupakan salah satu landasan yuridis bagi pengembangan Otonomi Daerah di Indonesia. Dalam Undang- Undang ini disebutkan bahwa pengembangan otonomi pada daerah Kabupaten atau Kota diselenggarakan dengan prinsip- prinsip demokrasi, peran masyarakat, pemerataan, dan keadilan serta memperhatikan potensi dan keanekaragaman daerah.

Kabupaten Jombang sebagai salah satu daerah otonom yang termasuk dalam Provinsi Jawa Timur tidak lepas dari dampak penerapan otonomi daerah. Dari hal tersebut Kabupaten Jombang dalam perolehan Pendapatan Asli Daerah sumber utamanya berasal dari pajak Daerah, retribusi daerah, pendapatan asli daerah lain- lain yang sah. Adapun komponen pajak daerah dan retribusi daerah yaitu : pajak kenderaan bermotor, bea balik nama kenderaan bermotor, pajak bahan bakar kenderaan bermotor, pajak hotel dan restoran, pajak hiburan, pajak reklame, pajak penerangan jalan, pajak pengambilan dan pengelolaan bahan galian golongan $\mathrm{C}$, serta pajak pemanfaatan air bawah tanah dan air permukaan.

Penelitian ini merupakan kelanjutan dari penelitian sebelumnya yang dilakukan oleh Aprilia Ristia Kaeng dan David P. E Saerang ( 2015 ) dari Universitas San Ratulangi Manado dengan judul "Analisis Pendapatan Asli Daerah Untuk Belanja Daerah Pada Pemerintah Kota Tomohon". Adapun perbedaan dengan penelitian sebelumnya yaitu terletak pada objek penelitiannya. Disini peneliti menggunakan objek penelitian pada Badan Pengelolaan Keuangan dan Aset Daerah Kabupaten Jombang. Berdasarkan uraian diatas, peneliti tertarik untuk melakukan penelitian lebih jauh mengenai kemampuan Pendapatan Asli Daerah ( PAD ) dalam memenuhi belanja daerah pada Pemerintah Daerah Kabupaten Jombang khususnya pada Badan Pengelolaan Keuangan dan Aset Daerah dan menuangkannya dalam judul skripsi yang berjudul :" Analisis Kemampuan Pendapatan Asli Daerah Untuk Memenuhi Besarnya Belanja Daerah Pada Pemerintah Daerah Kabupaten Jombang”

\section{Tujuan Penelitian}

Tujuan dari penelitian ini adalah untuk menganalisa dan memberikan penjelasan mengenai kemampuan pendapatan asli daerah dalam memenuhi belanja daerah pada Pemerintah Daerah Kabupaten Jombang.

\section{Manfaat yang dapat diharapkan}

Hasil penelitian ini diharapkan akan memberikan manfaat baik secara teoritis maupun secara praktis bagi semua pihak yang berkaitan dengan penelitian ini yaitu sebagai berikut :

1) Manfaat Teoritis 
Dapat memberikan tambahan wawasan dan pengetahuan tentang ilmu akuntansi sektor publik, sehingga dapat mengetahui pentingnya Pendapatan Asli Daerah terhadap pemenuhan belanja daerah.

2) Manfaat Praktis

Dapat dijadikan sebagai bahan informasi dan pertimbangan bagi kantor Pemerintah Daerah dalam mengoptimalkan penerimaan Pendapatan Asli Daerah ( PAD ) serta memanfaatkannya untuk belanja daerah yang lebih efektiv.

\section{B. Landasan Teori \\ Pemerintah Daerah}

Dalam penyelenggaraan Pemerintah Daerah di Indonesia didasarkan pada ketentuan Pasal 18 Undang - Undang Dasar 1945 yang menyatakan sebagai berikut" Negara Kesatuan Republik Indonesia dibagi atas daerah - daerah provinsi dan daerah provinsi itu dibagi atas kabupaten dan kota, yang tiap - tiap provinsi, kabupaten dan kota ini mempunyai pemerintah daerah yang diatur dengan Undang - Undang”. Dengan adanya kemajuan hukum dan ketatanegaraan di jaman globalisasi ini maka Pemerintah mengeluarkan Undang - Undang Nomor 23 Tahun 2014 tentang Pemerintahan Daerah sebagai pengganti dari Undang - Undang Nomor 32 Tahun 2004.

\section{Anggaran Pendapatan dan Belanja Daerah (APBD)}

Menurut UU No. 33 tahun 2004, "Anggaran pendapatan dan belanja daerah yang selanjutnya disebut APBD adalah suatu rencana keuangan tahunan daerah yang ditetapkan berdasarkan peraturan daerah tentang APBD". Menurut Saragih (2008: 127), "APBD merupakan suatu gambaran atau tolak ukur penting keberhasilan suatu daerah di dalam meningkatkan potensi perekonomian daerah. Artinya, jika perekonomian daerah mengalami pertumbuhan, maka akan berdampak positif terhadap peningkatan pendapatan daerah (PAD)". Anggaran Pendapatan dan Belanja Daerah (APBD), adalah rencana keuangan tahunan pemerintahan daerah yang disetujui oleh Dewan Perwakilan Rakyat Daerah.

Peraturan pemerintah menyatakan bahwa Anggaran Pendapatan dan Belanja Daerah selanjutnya disingkat (APBD) adalah suatu rencana keuangan tahunan Daerah sebagai dasar pengelolaan keuangan Daerah dalam tahun anggaran tertentu yang berisi sumber pendapatan dan penggunaan dana pemerintah daerah yang ditetapkan berdasarkan peraturan daerah. APBD pada hakekatnya merupakan salah satu instrumen kebijakan yang dipakai sebagai alat untuk meningkatkan pelayanan umum dan kesejahteraan masyarakat di daerah. Maka dari itu, Dewan Perwakilan Rakyat Daerah (DPRD) serta Pemerintah Daerah harusnya berupaya secara nyata dan terstruktur guna menghasilkan APBD yang dapat mencerminkan kebutuhan Riil masyarakat sesuai dengan potensi masing-masing Daerah serta dapat memenuhi tuntutan terciptanya anggaran daerah yang berorientasi pada kepentingan dan akuntabilitas publik. Penyusunan anggaran tidak bisa dilepaskan dari karakteristik suatu daerah, untuk dijadikan sebagai dasar pertimbangan dalam pengalokasian anggaran.

Disiplin anggaran APBD disusun dengan berorientasi pada kebutuhan masyarakat tanpa harus menigggalkan keseimbangan antara pembiayaan penyelenggaraan pemerintah,pembangunan dan pelayanan masyarakat. Oleh karena itu,anggaran yang disusun harus dilakukan berlandaskan azas efisiensi,tepat guna,tepat waktu dan dapat dipertanggungjawabkan. 


\section{Pengertian Pendapatan Asli Daerah}

Menurut Mardiasmo ( 2009 : 132 ) "pendapatan asli daerah merupakan penerimaan yang diperoleh dari beberapa sektor yaitu sektor pajak daerah, retribusi daerah, hasil perusahaan milik daerah, hasil pengelolaan kekayaan daerah dan pendapatan lain - lain yang sah".Di dalam Undang - Undang Nomor 23 Tahun 2014 tentang Perimbangan Keuangan Antara Pemerintah Pusat dan Pemerintah Daerah disebutkan bahwa sumber pendapatan daerah terdiri dari Pendapatan Asli Daerah dan Bagi Hasil Pajak dan Bukan Pajak. Pendapatan Asli Daerah sendiri terdiri atas pajak daerah, retribusi daerah, hasil pengolahan kekayaan daerah yang dipisahkan, serta lain-lain pendapatan asli daerah yang sah.

\section{Sistem Pemungutan Pajak Daerah}

Sistem pemungutan pajak dapat dikategorikan menjadi tiga yaitu official assesment system, self assesment system dan withholding system. Apabila dalam jangka waktu lima tahun berdasarkan pemeriksaan ditemukan adanya pajak daerah yang tidak atau kurang dibayar maka akan ditagih menerbitkan Surat Ketetapan Pajak Kurang Bayar ( SKPDKB ), apabila setelah diterbitkan SKPDKB berdasarkan data baru ternyata masih ada pajak daerah yang kurang bayar maka akan diterbitkan Surat Ketetapan Pajak Daerah Kurang Bayar Tambahan ( SKPDKBT ).

\section{Belanja Daerah}

Menurut Abdul Halim biaya atau belanja daerah merupakan penurunan dalam manfaat ekonomi selama periode akuntansi dalam bentuk arus keluar, atau deflasi aset, atau bisa dikatakan terjadinya utang yang mengakibatkan berkurangnya ekuitas dana, selain yang berkaitan dengan distribusi kepada para ekuitas dana. Secara umum Belanja dalam APBD dikelompokkan menjadi lima kelompok antara lain Belanja Administrasi Umum, Belanja Pegawai, Belanja Barang, Belanja Perjalanan Dinas, Belanja pemeliharaan, Belanja Operasional, Pemeliharaan Sarana, dan Prasarana Publik, Belanja Modal, Belanja Transfer, Belanja Tak Disangka.

\section{Teori Khusus}

Penelitian ini mengenai Analisis Kemampuan Pendapatan Asli Daerah Untuk Membiayai Besarnya Belanja Daerah Pada Pemerintah Daerah Kabupaten Jombang telah dilakukan penelitian sebelumnya. Salah satunya dilakukan oleh Aprislia Ristia Kaeng dan David P. E Saerang melakukan penelitian tentang Analisis Pendapatan Asli Daerah Untuk Belanja Daerah Pada Pemerintah Kota Tomohon Tahun 2015. Hasil penelitian ini menunjukan bahwa Pendapatan Asli Daerah berpengaruh signifikan terhadap belanja daerah.

Perlu diketahui bahwasanya Dana Perimbangan bisa disebut dengan pendapatan transfer. Hal ini berpedoman pada Permendagri nomor 13 Tahun 2006, Peraturan Pemerintah Nomor 71 Tahun 2010 Dan Undang - Undang Nomor 23 Tahun 2004. Perimbangan keuangan antara Pemerintah Pusat dan Pemerintahan Daerah adalah suatu sistem pembagian keuangan yang adil, proporsional, demokratis, transparan, dan efisien dalam rangka pendanaan penyelenggaraan desentralisasi, dengan mempertimbangkan potensi, kondisi, dan kebutuhan daerah, serta besaran pendanaan penyelenggaraan Dekonsentrasi dan Tugas Pembantuan. Perimbangan Keuangan antara Pemerintah dan Pemerintahan Daerah merupakan bagian pengaturan yang tidak terpisahkan dari sistem Keuangan Negara, dan dimaksudkan untuk mengatur sistem pendanaan atas kewenangan pemerintahan pusat yang diserahkan, dilimpahkan, dan ditugasbantukan kepada Daerah.

Dana Perimbangan adalah dana yang bersumber dari pendapatan APBN yang dialokasikan kepada Daerah untuk mendanai kebutuhan Daerah dalam rangka pelaksanaan Desentralisasi. Dana Perimbangan selain dimaksudkan untuk membantu Daerah dalam mendanai kewenangannya, juga bertujuan untuk mengurangi ketimpangan sumber pendanaan pemerintahan antara Pusat dan Daerah serta untuk mengurangi kesenjangan pendanaan pemerintahan antar-Daerah. Pendanaan tersebut menganut prinsip money follows function, 
yang mengandung makna bahwa pendanaan mengikuti fungsi pemerintahan yang menjadi kewajiban dan tanggung jawab masing-masing tingkat pemerintahan.

\section{Metode Penelitian \\ Rancangan Penelitian}

Berdasarkan latar belakang, rumusan masalah serta teori - teori dalam pembahasan maka dalam penelitian ini menggunakan metode deskriptif kualitatif. Yang mana dalam hal ini dijelaskan beberapa pengertian menurut para ahli. Satori dkk (2011: 25) mengungkapkan bahwa penelitian kualitatif yaitu suatu pendekatan penelitian yang mengungkapkan situasi sosial tertentu dengan mendeskripsikan kenyataan secara benar dibentuk dengan kata - kata berdasarkan teknik pengumpulan dan analisis data yang diperoleh dari situasi yang alamiah. Di sini, peneliti menggunakan metode penelitian deskriptif kualitatif karena penelitian ini menganalisis kemampuan Pendapatan Asli Daerah dalam memenuhi kebutuhan belanja daerah di Kabupaten Jombang.

Tabel 1. Operasional Variabel dan Indikator Variabel

\begin{tabular}{cl}
\hline $\begin{array}{c}\text { Operasional } \\
\text { Variabel }\end{array}$ & \multicolumn{1}{c}{ Indikator Variabel } \\
\hline $\begin{array}{c}\text { Pendapatan Asli } \\
\text { Daerah }\end{array}$ & $\begin{array}{l}\text { Pajak Daerah } \\
\text { Retribusi Daerah } \\
\end{array}$ \\
& Hasil Pengelolaan Kekayaan \\
& Daerah Yang Dipisahkan \\
& Lain - Lain PAD yang \\
& Dipisahkan \\
& Belanja Langsung \\
Belanja Daerah & Belanja Tidak Langsung \\
\hline
\end{tabular}

\section{Teknik Analisis Data}

\section{Reduksi Data}

Reduksi data bukanlah suatu hal yang terpisah dari analisis. Reduksi data diartikan sebagai proses pemilihan, pemusatan perhatian pada penyederhanaan, pengabstraksian, dan transformasi data kasar yang muncul dari catatan-catatan tertulis di lapangan. Reduksi data merupakan suatu bentuk analisis yang menajamkan, menggolongkan, mengarahkan, membuang yang tidak perlu, dan mengorganisasi data sedemikian rupa sehingga kesimpulankesimpulan akhirnya dapat ditarik dan diverivikasi. Jadi dalam penelitian kualitatif dapat disederhanakan dan ditransformasikan dalam aneka macam cara: melalui seleksi ketat, melalui ringkasan atau uraian sigkat, menggolongkan dalam suatu pola yang lebih luas, dan sebagainya.

\section{Triangulasi}

Selain menggunakan reduksi data peneliti juga menggunakan teknik Triangulasi sebagai teknik untuk mengecek keabsahan data.. Triangulasi dengan sumber artinya membandingkan dan mengecek balik derajat kepercayaan suatu informasi yang diperoleh melalui waktu dan alat yang berbeda dalam penelitian kualitatif (Patton,1987:331). Sementara itu, dalam catatan Tedi Cahyono dilengkapi bahwa dalam riset kualitatif triangulasi merupakan proses yang harus dilalui oleh seorang peneliti disamping proses lainnya, dimana proses ini menentukan aspek validitas informasi yang diperoleh untuk kemudian disusun dalam suatu penelitian. Murti B., 2006 menyatakan bahwa tujuan umum dilakukan triangulasi adalah untuk meningkatkan kekuatan teoritis, metodologis, maupun interpretatif dari sebuah riset. 


\section{Analisis Varians Pendapatan Daerah}

Analisis Varians Pendapatan Derah dilakukan dengan cara menghitung selisih antara realisasi pendapatan dengan yang dianggarkan. Informasi selisih anggaran tersebut sangat membantu pengguna laporan dalam memahami dan menganalisis kinerja keuangan pendapatan. Pada prinsipnya, anggaran pendapatan merupakan batas minimal jumlah pendapatan yang ditargetkan harus diperoleh oleh Pemerintah Daerah. Pemerintah Daerah dikatakan memiliki kinerja keuangan pendapatan yang baik apabila mampu memperoleh pendapatan melebihi jumlah yang dianggarkan (target anggaran). Sebaliknya, apabila realisasi pendapatan dibawah jumlah yang dianggarkan, maka hal itu dinilai kurang baik. Selisih lebih pendapatan merupakan selisih menguntungkan (Favourable Variance), sedangkan selisih kurang merupakan selisih yang tidak menguntungkan (Unfavourable Variance). Berikut ini rumus untuk menghitung analisis varians Pendapatan daerah (Halim, 2007) :

$$
\text { Persentase Varians }=\frac{\text { Realisasi Anggaran Pendapatan }}{\text { Anggaran Pendapatan }} \times 100 \%
$$

\section{Derajat Desentralisasi}

Derajat desentralisasi fiskal atau otonomi fiskal adalah kemampuan pemerintah dalam rangka meningkatkan pendapatan asli daerah guna membiayai pembangunan. Derajat desentralisasi fiskal menunjukkan derajat kontribusi PAD terhadap total penerimaan daerah. Adapun tujuan yang ingin dicapai dari terselenggaranya desentralisasi fiskal antara lain untuk memperkecil kesenjangan antara keuangan pemerintah pusat dan pemerintah daerah, serta meningkatkan kualitas pelayanan publik Rasio dirumuskan Desentralisasi Fiskal dengan membagi antara Pendapatan Asli Daerah dengan Total Penerimaan Daerah. Derajat desentralisasi fiskal dapat dihitung dengan menggunakan rumus sebagai berikut:

$$
\text { Rasio Derajat Desentralisasi }=\frac{\text { Pendapatan Asli Daerah }}{\text { Total Pendapatan Daerah }} \times 100 \%
$$

Sumber: Bisma dan Susanto, 2010

Kriteria penilaian tingkat desentralisasi fiskal dapat dikategorikan seperti tabel 3.2 berikut ini:

\section{Tabel 2. Kriteria Kinerja Keuangan Rasio Desentralisasi Fiskal}

\begin{tabular}{ll}
\hline $\begin{array}{c}\text { Persentase Derajat Desentralisasi } \\
\text { Fiskal }\end{array}$ & Kriteria Rasio Desentralisasi \\
\hline $00,00 \%-10,00 \%$ & Sangat Kurang \\
$10,01 \%-20,00 \%$ & Kurang \\
$20,01 \%-30,00 \%$ & Cukup \\
$30,01 \%-40,00 \%$ & Sedang \\
$40,01 \%-50,00 \%$ & Baik \\
$>50,00 \%$ & Sangat Baik \\
\hline
\end{tabular}

Sumber: Tim Litbang Depdagri-Fisipol UGM dalam (Bisma, 2010)

\section{Rasio Ketergantungan Keuangan Daerah}

Rasio ketergantungan keuangan daerah dihitung dengan cara membandingkan jumlah pendapatan transfer yang diterima oleh penerimaan daerah dengan total penerimaan daerah. Semakin tinggi rasio ini maka semakin besar tingkat ketergantungan pemerintah daerah terhadap pemerintah pusat dan pemerintah propinsi. 
Rasio Ketergantungan Keuangan Daerah $=\frac{\text { Pendapatan } \text { Transfer }}{\text { Total Pendapatan Daerah }} X 100 \%$

Sumber : Mardiasmo ( $2009: 165$ )

Kriteria untuk menetapkan ketergantungan keuangan daerah dapat dilihat pada Tabel 3.3 berikut ini:

Tabel 3. Kriteria Penilaian Ketergantungan Keuangan Daerah

$\begin{array}{cc}\begin{array}{c}\text { Prosentase PAD Terhadap Total } \\ \text { Penerimaan Non Subsidi }\end{array} & \begin{array}{c}\text { Ketergantungan Keu } \\ \text { Daerah } \\ 0,00-10.00\end{array} \\ 10,01-20,00 & \text { Sangat Rendah } \\ 20,01-30,00 & \text { Rendah } \\ 30,01-40,00 & \text { Sedang } \\ 40,01-50,00 & \text { Cukup } \\ >50,00 & \text { Tinggi } \\ \end{array}$

Sumber: Tim Litbang Depdagri- Fisipol UGM, 2010

Rasio Efektivitas Pendapatan Asli Daerah

Rasio efektivitas menggambarkan kemampuan pemerintah daerah dalam merealisasikan PAD yang direncanakan dibandingkan dengan target yang ditetapkan berdasarkan potensi riil daerah. Keberhasilan suatu pemerintah daerah dalam melaksanakan roda pemerintahan, salah satunya bisa diukur dengan efektivitas pelaksanaan anggaran tersebut.

Rasio Efektivitas PAD $=\frac{\text { Realisasi Penerimaan } P A D}{\text { Target Penerimaan }} x 100 \%$

Sumber: Halim (2002:234)

Tabel 4. Kriteria Keuangan Daerah

\begin{tabular}{cc}
\hline Persentase Kinerja Keuangan & Kriteria \\
\hline Diatas $100 \%$ & Sangat Efektif \\
$90 \%-100 \%$ & Efektif \\
$80 \%-90 \%$ & Cukup Efektif \\
$60 \%-80 \%$ & Kurang Efektif \\
Kurang dari $60 \%$ & Tidak Efektif \\
\hline
\end{tabular}

Sumber : Dasril Munir dalam Yumardi

\section{Rasio Efisiensi Belanja}

Rasio efisiensi belanja daerah dirumuskan sebagai berikut (Mahmudi, 2010:166) :

$$
\text { Rasio Efisiensi Belanja }=\frac{\text { Realisasi Belanja }}{\text { Anggaran Belanja }} X 100 \%
$$

\section{Menarik Kesimpulan}

Kegiatan analisis ketiga adalah menarik kesimpulan dan verivikasi. Ketika kegiatan pengumpullan data dilakukan, seorang penganalisis kualitatif mulai mencari arti benda-benda, mencatat keteraturan, pola-pola, penjelasan, konfigurasi-konfigurasi yang mungkin, alur sebab akibat, dan proposisi. Kesimpulan yang mula-mulanya belum jelas akan meningkat menjadi 
lebih terperinci. Kesimpulan-kesimpulan "final" akan muncul bergantung pada besarnya kumpulan-kumpulan catatan lapangan, pengkodeannya, penyimpanan, dan metode pencarian ulang yang digunakan, kecakapan peneliti, dan tuntutan pemberi dana, tetapi sering kali kesimpulan itu telah sering dirumuskan sebelumnya sejak awal.

\section{Hasil Dan Pembahasan}

\section{Analisis Varians}

Realisasi anggaran pendapatan merupakan batas minimal jumlah pendapatan yang ditargetkan harus diperoleh oleh pemerintah daerah. Analisis varians (selisih) anggaran pendapatan dilakukan dengan cara menghitung selisih antara realisasi pendapatan dengan jumlah yang dianggarkan. Biasanya selisih anggaran sudah diinfromasikan dalam Laporan Realisasi Anggaran (LRA) yang disajikan oleh pemerintah daerah. Informasi selisih anggaran tersebut sangat membantu pengguna laporan keuangan dalam memahami dan menganalisis kinerja pendapatan.Berikut ini merupakan data anggaran pendapatan dan realisasi anggaran Pendapatan yang diperoleh dari BPKAD Kabupaten Jombang Tahun 2012 sampai dengan Tahun 2017 :

Tabel 5. Varians Realisasi Anggran Pendapatn dan Anggaran Pendapatan

\begin{tabular}{|c|c|c|c|c|}
\hline Tahun & $\begin{array}{c}\text { Realisasi } \\
\text { Pendapatan }\end{array}$ & $\begin{array}{c}\text { Anggaran } \\
\text { Pendapatan }\end{array}$ & $\begin{array}{c}\text { Varians } \\
\text { Pendapatan }\end{array}$ & $\begin{array}{c}\text { Kriteria } \\
\text { Kemampuan }\end{array}$ \\
\hline 2012 & $1.439 .221 .547 .802,76$ & $1.397 .450 .431 .602,18$ & $\begin{array}{c}41.771 .116 .20 \\
0,58\end{array}$ & Fovorable \\
\hline 2013 & $1.567 .610 .980 .536,59$ & $1.572 .846 .963 .948,00$ & $\begin{array}{c}5.235 .983 .411 \\
41)\end{array}$ & Unfovorable \\
\hline 2014 & $1.905 .860 .371 .275,38$ & $1.799 .761 .921 .253,97$ & $\begin{array}{c}106.098 .450 .0 \\
21,41\end{array}$ & Favorable \\
\hline 2015 & $2.151 .287 .874 .052,96$ & $2.135 .865 .342 .084,20$ & $\begin{array}{c}15.422 .531 .96 \\
8,76\end{array}$ & Favorable \\
\hline 2016 & $2.257 .099 .357 .781,47$ & $2.234 .904 .907 .100,67$ & $\begin{array}{c}22.194 .450 .68 \\
0,80\end{array}$ & Favorable \\
\hline 2017 & $2.517 .003 .141 .056,17$ & $2.534 .376 .986 .170,68$ & $\begin{array}{c}(17.373 .845 .11 \\
4,51)\end{array}$ & Unfovarable \\
\hline
\end{tabular}

Sumber : Data Diolah, 2018

Analisis varians secara umum menunjukkan bahwa Kinerja Keuangan Pendapatan Asli Daerah Kabupaten Jombang selama enam tahun terakhir dinyatakan baik. Hal ini terlihat dari varians pendapatan yang ditunjukkan sebagian besar tahun yang diteliti mengalami selisih yang diharapkan (Favourable Variance). Varians pendapatan yang paling rendah terjadi pada tahun 2017 yaitu Rp. 17.373.845.114,51, sedangkan varians pendapatan yang paling tinggi terjadi pada tahun 2012 yaitu Rp. 41.771.116.200,58. Hasil penelitian ini mendukung pendapat yang dikemukakan oleh Mahmudi ( 2010 : 137 ) yaitu Pemerintah Kabupaten/ Kota dikatakan memiliki kinerja pendapatan yang baik apabila dapat memperoleh pendapatan yang melebihi jumlah yang dianggarkan.

\section{Derajat Desentralisasi}

Capaian hasil perhitungan Derajat Desentralisasi akan direkapitulasi dan diukur sesuai kriteria dengan menggunakan kriteria berikut ini :

\section{Tabel 6. Perhitungan Derajat Desentralisasi Pemerintah Daerah Kabupaten Jombang} Tahun 2012 - 2017 


\begin{tabular}{|c|c|c|c|c|}
\hline \multirow[b]{2}{*}{$\begin{array}{l}\text { Tahun } \\
\text { (1) }\end{array}$} & \multirow[b]{2}{*}{$\begin{array}{c}\text { Realisasi PAD } \\
\text { (2) }\end{array}$} & \multicolumn{2}{|c|}{ Keterangan } & \multirow[b]{2}{*}{$\begin{array}{c}\text { Kriteria } \\
\text { Kemampuan } \\
\text { (5) }\end{array}$} \\
\hline & & $\begin{array}{c}\text { Total Pendapatan } \\
\text { Daerah } \\
\text { (3) }\end{array}$ & $\begin{array}{c}\text { Rasio Derajat } \\
\text { Desentralisasi } \\
(4)=(2):(3) * 10 \\
0\end{array}$ & \\
\hline 2012 & $164.389 .353 .734,76$ & $\begin{array}{c}\text { 1.439.221.547.802 } \\
76\end{array}$ & $5 \%$ & Sangat Kurang \\
\hline 2013 & $185.091 .678 .239,59$ & $\begin{array}{c}\text { 1.567.610.980.536 } \\
59\end{array}$ & $11 \%$ & Kurang \\
\hline 2014 & $304.065 .301 .093,38$ & $\begin{array}{c}1.905 .860 .371 .275 \\
38\end{array}$ & $15 \%$ & Kurang \\
\hline 2015 & $363.963 .252 .971,96$ & $\begin{array}{c}2.151 .287 .874 .052 \\
96\end{array}$ & $16 \%$ & Kurang \\
\hline 2016 & $374.141 .185 .825,47$ & $\begin{array}{c}2.257 .099 .357 .781 \\
47\end{array}$ & $16 \%$ & Kurang \\
\hline 2017 & $521.236 .583 .750,17$ & $\begin{array}{c}2.517 .003 .141 .056 \\
17\end{array}$ & $20,7 \%$ & Cukup \\
\hline
\end{tabular}

\section{Sumber : Data Diolah, 2018}

Berdasarkan tabel 4.8 dapat diketahui bahwa Rasio Derajat Desentralisasi Pemerintah Daerah Kabupaten Jombang tahun 2012 : 5\%, 2013 : 11\%, 2014 : 15\%, 2015 : 16\%, 2016 : 16\%, 2017 : 20,7\%. Ini berarti kewenangan dan tanggung jawab yang diberikan oleh Pemerintah Pusat kepada Pemerintah Daerah Kabupaten Jombang untuk menggali dan mengelola sumber daya yang dimiliki masih rendah. Berdasarkan hasil analisis terhadap rata rata tingkat desentralisasi Pemerintah Daerah Kabupaten Jombang sepanjang tahun 2012 sampai dengan tahun 2017 adalah 14\% sehingga diklasifikasikan menurut kriteria penilaian tingkat desentralisasinya kurang.

\section{Rasio Ketergantungan Keuangan Daerah}

Tabel 7. Perhitungan Ketergantungan Keuangan Daerah Tahun 2012 - 2017

\begin{tabular}{ccccc}
\hline $\begin{array}{c}\text { Tahu } \\
\mathbf{n}\end{array}$ & $\begin{array}{c}\text { Pendapatan } \\
\text { Transfer }\end{array}$ & $\begin{array}{c}\text { Keterangan } \\
\text { Pendal } \\
\text { Daerah }\end{array}$ & $\begin{array}{c}\text { Rasio } \\
\text { Ketergantung } \\
\text { an Keuangan } \\
\mathbf{( 4 ) = ( 2 ) : ( 3 ) * 1 0}\end{array}$ & $\begin{array}{c}\text { Kriteria } \\
\text { Kemampua } \\
\mathbf{n}\end{array}$ \\
\hline $\mathbf{1})$ & $\mathbf{( 2 )}$ & $\mathbf{( 3 )}$ & $\mathbf{( 5 )}$ & Sangat Tinggi \\
\hline 2012 & 997.447 .923 .900 & $\begin{array}{c}1.439 .221 .547 .80 \\
2,76\end{array}$ & $70 \%$ & Sangat Tinggi \\
2013 & 1.060 .053 .279 .863 & $\begin{array}{c}1.567 .610 .980 .53 \\
6,59\end{array}$ & $67 \%$ & Sangat Tinggi \\
2014 & 1.131 .290 .917 .695 & $\begin{array}{c}1.945 .860 .371 .27 \\
5,38\end{array}$ & $59 \%$ & Sangat Tinggi \\
2015 & 1.617 .503 .926 .481 & $\begin{array}{c}2.151 .287 .874 .05 \\
2,96\end{array}$ & $75 \%$ & Sangat Tinggi \\
2016 & 1.656 .569 .041 .857 & $\begin{array}{c}2.257 .099 .357 .78 \\
1,47\end{array}$ & $73 \%$ & Sangat Tinggi \\
\hline
\end{tabular}

Sumber : Data Diolah, 2018

Berdasarkan perhitungan tabel 4.9 menunjukkan bahwa selama periode 6 tahun yaitu tahun 2012 sampai dengan tahun 2017 tingkat ketergantungan keuangan daerah terhadap pendapatan transfer sangat tinggi. Pada tahun 2015 tingkat ketergantungan keuangan daerah berada pada rasio yang sangat tinggi yaitu $75 \%$. Dari hasil ini dapat dikatakan bahwa 
Pemerintah Daerah Kabupaten Jombang masing sangat tergantung terhadap pendapatan transfer.

Tabel 8. Perhitungan Efektivitas Pemerintah Asli Daerah Kabupaten Jombang Tahun 2012 - 2017

\begin{tabular}{|c|c|c|c|c|}
\hline \multirow[b]{2}{*}{ Tahun } & \multicolumn{4}{|c|}{ Keterangan } \\
\hline & $\begin{array}{c}\text { Realisasi } \\
\text { Pendapatan }\end{array}$ & Target PAD & Rasio Efetivitas & $\begin{array}{c}\text { Kriteria } \\
\text { Kemampuan }\end{array}$ \\
\hline (1) & (2) & (3) & $(4)=(2):(3) * 100$ & (5) \\
\hline 2012 & $164.389 .353 .734,76$ & 1.397.450.431.602,18 & $118 \%$ & $\begin{array}{l}\text { Sangat } \\
\text { Efektiv }\end{array}$ \\
\hline 2013 & $185.091 .678 .239,59$ & 1.572.846.963.948,00 & $107 \%$ & $\begin{array}{l}\text { Sangat } \\
\text { Efektiv }\end{array}$ \\
\hline 2014 & $304.065 .301 .093,38$ & 1.799.761.921.253,97 & $119 \%$ & $\begin{array}{l}\text { Sangat } \\
\text { Efektiv }\end{array}$ \\
\hline 2015 & $363.963 .252 .971,96$ & $2.135 .865 .342 .084,20$ & $114 \%$ & $\begin{array}{l}\text { Sangat } \\
\text { Efektiv }\end{array}$ \\
\hline 2016 & $374.141 .185 .825,47$ & 2.234.904.907.100,67 & $108 \%$ & $\begin{array}{l}\text { Sangat } \\
\text { Efektiv }\end{array}$ \\
\hline 2017 & $521.236 .583 .750,17$ & 2.534.376.986.170,68 & $105 \%$ & $\begin{array}{l}\text { Sangat } \\
\text { Efektiv }\end{array}$ \\
\hline
\end{tabular}

Berdasarkan perhitungan pada tabel 4.10 menunjukkan bahwa anggaran Pendapatan Asli Daerah Kabupaten Jombang selalu mengalami kenaikan dan penurunan dari tahun ke tahun. Namun berdasarkan skala interval menurut Dasril Munir dalam Yumardi dalm periode tahun 2012 sampai dengan tahun 2017 Pemerintah Kabupaten Jombang sudah sangat efektif dalam mengelola keuangan daerahnya. Hal ini terbukti dari kriteria yang yang didaptkan selama 6 periode tersebut. Kemampuan keuangan Pemerintah Daerah dalam mengelola keuangannya yang paling efektiv terjadi pada tahun 2014. Berdasarkan hal ini bisa disimpulkan bahwasanya pencapaian tujuan anggaran daerah sudah berhasil.

Rasio Efisiensi Belanja

Tabel 9. Perhitungan Rasio Efesiensi Belanja Pemerintah Daerah Kabupaten Jombang

Tahun 2012 - 2017

\begin{tabular}{|c|c|c|c|c|}
\hline \multirow[b]{2}{*}{$\begin{array}{c}\text { Tahun } \\
\text { (1) }\end{array}$} & \multicolumn{4}{|c|}{ Keterangan } \\
\hline & $\begin{array}{c}\text { Total Realisasi } \\
\text { Belanja Daerah } \\
\text { (2) }\end{array}$ & $\begin{array}{c}\text { Total Anggaran } \\
\text { Belanja Daerah } \\
\text { (3) }\end{array}$ & $\begin{array}{l}\text { Rasio Efisiensi } \\
(4)=(2):(3) * 10 \\
0\end{array}$ & $\begin{array}{c}\text { Kriteria } \\
\text { Kemampuan } \\
\text { (5) }\end{array}$ \\
\hline 2012 & $1.363 .382 .391 .746,28$ & $\begin{array}{l}\text { 1.535.646.851.255, } \\
47\end{array}$ & $88 \%$ & Efisien \\
\hline 2013 & $1.559 .047 .056 .626,78$ & $\begin{array}{l}\text { 1.797.064.680.896, } \\
77\end{array}$ & $87 \%$ & Efisien \\
\hline 2014 & 1.780.114.993.045,15 & $\begin{array}{l}2.029 .130 .565 .410, \\
55\end{array}$ & $87 \%$ & Efisien \\
\hline 2015 & 2.164.953.026.633,20 & $\begin{array}{l}2.485 .612 .912 .923, \\
01\end{array}$ & $87 \%$ & Efisien \\
\hline 2016 & 2.364.581.573.271,18 & $\begin{array}{l}2.570 .651 .376 .368, \\
24\end{array}$ & $92 \%$ & Efisien \\
\hline 2017 & $\begin{array}{l}2.401 .430 .893 .002, \\
94\end{array}$ & $\begin{array}{l}2.762 .750 .303 .18 \\
4,68\end{array}$ & $87 \%$ & Efisien \\
\hline
\end{tabular}

Sumber : Data Diolah, 2018

JAD: Jurnal Riset Akuntansi dan Keuangan Dewantara

Vol 2 No 1, Januari-Juni 2019

https://ejournal.stiedewantara.ac.id/index.php/JAD/issue/view/42

Hal $20-23$ 
Analisis efisensi Belanja Daerah menunjukkan bahwa kabupaten Jombang telah melakukan efisensi belanja untuk tahun 2012 sampai dengan tahun 2017. Hal ini ditunjukkan dengan realisasi anggaran belanja Kabupaten Jombang yang tidak terdapat angka melebihi anggaran belanja. Hasil ini mendukung pendapat Mahmudi ( 2010 : 166 ) jika angka yang dihasilkan dari rasio kurang dari 100\% maka dinilai telah melakukan efisiensi anggaran.

Dilihat dari tabel 4.11 rasio yang efisen belanja terendah terdapat pada tahun $2013-2014$ dan 2017, kemudian di tahun 2012 sebesar $88 \%$ dan di tahun 2016 terdapat presentase tertinggi yaitu 92\%. Namun perlu diketahui bahwa Pendapatan Asli Daerah yang berasal dari pendapatan Rumah Sakit Umum Daerah ( RSUD ) tidak bisa dikelola untuk kepentingan lain kecuali hanya digunakan dalam lingkup Rumah Sakit Umum Daerah tersebut. Berikut tabel penerimaan pendapatan urusan wajib kesehatan :

Tabel 10. Ringkasan Pendapatan RSUD

\begin{tabular}{cc}
\hline Tahun & Anggaran \\
\hline 2012 & $76.000 .000 .000,00$ \\
2013 & $92.864 .792 .934,00$ \\
2014 & $115.355 .729 .276,25$ \\
2015 & $118.000 .000 .000,00$ \\
2016 & $143.997 .610 .000,00$ \\
2017 & $197.735 .770 .668,87$ \\
\hline
\end{tabular}

Sumber : BPKAD Kabupaten Jombang

Berikut ini disajikan tabel kontribusi Pendapatan Asli Daerah dengan Belanja Daerah pada Tahun 2012 sampai dengan Tahun 2017 :

Tabel 11. Kontribusi Pendapatan Asli Daerah dengan Belanja Daerah

\begin{tabular}{cccc}
\hline Tahun & $\begin{array}{c}\text { Pendapatan Asli } \\
\text { Daerah }\end{array}$ & Belanja Daerah & $\begin{array}{c}\text { Prosentase } \\
\text { Kontribusi }\end{array}$ \\
\hline 2012 & $1.439 .221 .547 .802,76$ & $1.363 .382 .391 .746,28$ & $105,6 \%$ \\
2013 & $1.567 .610 .980 .536,59$ & $1.559 .047 .056 .626,78$ & $100,6 \%$ \\
2014 & $1.905 .860 .371 .275,38$ & $1.780 .114 .993 .045,15$ & $107 \%$ \\
2015 & $2.151 .287 .874 .052,96$ & $2.164 .953 .026 .633,20$ & $99,4 \%$ \\
2016 & $2.257 .099 .357 .781,47$ & $2.364 .581 .573 .271,18$ & $95,5 \%$ \\
2017 & $2.517 .003 .141 .056,17$ & $2.401 .430 .893 .002,94$ & $105 \%$ \\
\hline
\end{tabular}

Sumber : Data Diolah (2018)

\section{E. Penutup}

\section{Simpulan}

Berdasarkan analisis yang dilakukan dalam penelitian yang berjudul Analisis Kemampuan Pendapatan Asli Daerah Untuk Memenuhi Belanja Daerah dapat disimpulkan sebagai berikut:

a. Kemampuan Pendapatan Asli Daerah Kabupaten Jombang dilihat dari Analisis Varians Pendapatan Daerah Pemerintah Daerah sudah memenuhi kebutuhan dana untuk penyelenggaraan tugas- tugas pemerintah, pembvangunan, dan dinyatakan baik.

b. Kemampuan Pendapatan Asli Daerah Kabupaten Jombang dilihat dari Derajat Desentralisasi selama tahun 2012 sampai dengan tahun 2017 secara umum dinyatakan kurang baik dengan rata - rata sebesar $14 \%$.

c. Kemampuan Pendapatan Asli Daerah dilihat dari rasio ketergantungan dari tahun 2012 2017 sangat tinggi.

d. Kemampuan Pendapatan Asli Daerah dilihat dari segi evektifitas PAD Pemerintah Daerah Kabupaten Jombang selama tahun 2012 sampai dengan tahun 2017, secara umum dinyatakan sangat evektif. 
e. Kemampuan Pendapatan Asli Daerah dilihat dari Efisiensi Belanja Daerah, realisasi anggaran Belanja Pemerintah Daerah Kabupaten Jombang tidak terdapat angka yang melebihi anggaran belanja. Hal ini menunjukkan bahwa Pemerintah Daerah Kabupaten Jombang telah melakukan efisiensi belanja.

\section{Saran}

Berdasarkan hasil penelitian disarankan kepada :

1. Bagi Pemerintah Daerah

Pemerintah Daerah Kabupaten Jombang sebaiknya lebih meningkatkan lagi Pendaptan Asli Daerah dan juga Pemerintah Kabupaten Jombang bisa dapat menggali potensi dan sumber daya yang ada di Kabupaten Jombang.

Meningkatkan terus kinerja pengelolaan terhadap realisasi APBD, agar Kabupaten Jombang mampu menjadi kota yang mandiri tanpa ketergantungan yang besar terhadap bantuan dana dari pemerintah pusat maupun provinsi.

2. Bagi Peneliti Selanjutnya

Lebih mendalami mengenai kinerja keuangan pada Pemerintah Daerah dengan menggunakan lebih banyak rasio lagi sehingga hasil penelitiannya bisa lebih andal dan akurat.

\section{DAFTAR PUSTAKA}

Argi, Ridho. 2011. “Analisis BelanjaDaerah dan Faktor - Faktor Yang Mempengaruhinya di Kabupaten dan Kota Provinsi Jawa Tengah Periode 2004-2009” (Skripsi S-1).Semarang FE Universitas Diponegoro.

BPKAD Kabupaten Jombang. jombangkab.go.id/index.php/page/detail/bpkad-strukturorganisasi.html (diakses tanggal 1Agustus 2018)

Darise Nurlan.2007.Pengelolaan Keuangan Daerah. Indeks.

Halim. Abdul., 2001. Bunga Rampai Manajemen Keuangan Daerah. Jogjakarta: UPP AMP YKPN.

Halim, A, 2001, Manajemen Keuangan Daerah, Edisi Pertama, Yogyakarta: UPF

Akademi Manajemen Keuangan Perusahaan YKPN.

Halim, A, 2002, Akuntansi Sektor Publik: Akuntansi Keuangan Daerah, Edisi Pertama, Jakarta: Salemba Empat.

Kuncoro, M, 2004, Otonomi Daerah: Reformasi, Perencanaan, Strategi, dan Peluang, Jakarta: Erlangga.

Kusumawardani, Nurul Kamaril. 2006. "Analisis PAD Atas Besarnya Belanja Operasional Pada Pemerintah Daerah Kabupaten Kuningan” (Skripsi S-1 Progdi Akuntansi ). Bandung: FE Universitas Widyatama.

Mardiasmo, 2002, Otonomi dan Manajemen Keuangan Daerah, Yogyakarta: ANDI.

Mardiasmo.2002. Akuntansi Sektor Publik. Yogyakarta: ANDI

Mohammad Nazir. 2003. Metode Penelitian. Jakarta : Ghalia Indonesia.

Peraturan Mentri Dalam Negeri No. 13 Tahun 2006.

Peraturan Pemerintah No.71 Tahun 2010.

Rahim, Syamsuri. 2008. Analisis Kemampuan Pendapatan Asli Daerah dalam

Membiayai Belanja Daerah, Jurnal Ichsan Gorontalo Volume 3 No. 2.Makassar : FE Universitas Muslim Indonesia.

Sasana, Hadi. 2011. Analisis Determinan Belanja Daerah Di Kabupaten/KotaProvinsi Jawa Barat Dalam Era dan Desentralisasi Fiskal, Jurnal Bisnis dan Ekonomi (JBE) Universitas Diponegoro Semarang Volume 18 No. 1 Halaman 46-58. Semarang.

UU No. 23 Tahun 2014 tentang Pemerintahan Daerah. 
UU No. 23 Tahun 2014 tentang Perimbangan Keuangan Antara Pemerintah Pusat dan Pemerintah Daerah.

Utomo, L. P., Asyik, N. F., \& Hermanto, S. B. (2017). Belanja Modal Memediasi Pengaruh Pendapatan Daerah Terhadap Pertumbuhan Ekonomi Daerah Otonomi Khusus. Jurnal Ilmiah Akuntansi dan Bisnis, 115-128. 